\title{
ACCESSION BY THE UNITED STATES TO THE UNITED NATIONS CONVENTION ON THE RECOGNITION AND ENFORCEMENT OF FOREIGN ARBITRAL AWARDS
}

\author{
LEONARD V, QUUIGLEY广
}

The 1958 United Nations Convention on the Recognition and Enforcement of Foreign Arbitral Awards represents another step in the continuing attempt by businessmen to achieve a non-judicial solution of their day-to-day disputes. From the days of the early English "piepowder" courts, where merchants with the dust of the market still on their feet stepped into a tribunal of merchants for swift resolution of their disputes, businessmen have preferred arbitration, a process which they think combines finality of decision with speed, low expense, and flexibility in the selection of principles and mercantile customs to be used in solving a problem, over litigation. The needs of the businessmen are basically these: enforcement of an agreement to submit future disputes to arbitration - both by ordering a recalcitrant party to arbitrate and by staying court proceedings instituted in disregard of the agreement-and enforcement of the award resulting from a voluntary or involuntary submission of an existing dispute to arbitration. But the history of arbitration is replete with misunderstanding and opposition from judicial and legislative bodies, and the present arbitral framework is a myriad of complex problems.

The English common law courts early declared that contracts to submit future disputes to arbitration were revocable at any time prior to the issuance of an award. I This judicial suspicion of "future dispute" clauses, whether based on jealousy over an expected "ouster of jurisdiction" of the courts or based upon a public policy that the decision to submit a dispute to arbitration should be made at the time it has arisen, was carried over into the common law of all the American states. ${ }^{2}$ While this hostility remains the judicial attitude of most of the states ${ }^{3}$-and has even been codified by some ${ }^{4}$ - several

†Member, New York Bar.

1. Vynior's Càse, 8 Co. 81b, 77 Eng.' Rep. 597 (स.B. 1609)."

2. For surveys of the development of commercial arbitration in England and the United States, sce Sayre, Development of Commercial Arbitratioir Läw, 37-YALE L.J. 595 (1928), and Jones, History of Commercial Arbitration in England and the United States: A Summary Vieze, in Domke, Internationai Trade Arbitration 127 (1958) . [hereinafter cited as Doarke].

3. A survey of state laws is contained in KELLOR, Arbirration IN Action (1941). For a list of general arbitration statutes in the United States, see 12 ARB. J. (n.s.) 38-44 (1957).

4. E.g., Okza. Stat. tit. 15, § 216 (1951). 
states have enacted legislation which rejects the common law in an effort to afford the businessman the arbitration he has contracted for. ${ }^{5}$

On the federal level, the drive for arbitration received assistance from the enactment of the Federal Arbitration Act in $1925 .{ }^{7}$ This Act provides for the specific enforcement of arbitration agreements in the federal courts, ${ }^{8}$ and stay of litigation instituted in defiance of the arbitration agreement ${ }^{3}$ it authorizes confirmation of the arbitral award by a federal court of the district in which the award is rendered..$^{\mathbf{1 0}}$ But the number of arbitration agreements to which this Act applies is limited, ${ }^{11}$ and the litigant who desires to enlist the aid of the Federal Arbitration Act must still satisfy all requirements of federal jurisdiction. ${ }^{12}$

5. The New York Statute, N.Y. Civ. Prac. Acr $\S 1448-69$, is the prototype. Other statutes enacted in aid of arbitration: ArIz. Rev. Stat. ANN. $\$ \S 12-1501$ to -1511 (1956); Cal. Civ. Proc. Code $\$ \S 1280-93$; Conn. Gen. Stat. Rev. $\$ \$ 52-408$ to -424 (1958); Fla. Stat. $\$ \S 57.01-.09$ (1957); Hawamr Rev. Laws $\$ \$ 188-1$ to -15 (1955); La. Rev. Stat. $\$ \$ 9: 4201-: 4217$ (1950) ; ME. Rev. Stat. Ann. ch. 121, §§ 1-5 (1954); Mass. Gen. Laws ch. 251, \$§ 1-22 (1932) ; Mich. Stat. Ann. \$\$ 27.2483-.2505 (1943) ; Minn. Stat. Ann. $\$ \$ 572.01-.07$ (1947) ; N.H. Rev. Stat. Ann. $\$ \$ 542: 1-: 10$ (1955); N.J. Stat. ANw. $\$ \S$ 2a:24-1 to -11 (1952); Ohio Rev. Code Ans. \$§ 2711:01-:15 (Page 1954); Ore. Rev. Stat. §§ 33.210-.340 (1959); PA. Stat. ANn. tit. 5, \$§ 1-209 (1930) ; R.I. Gen. Laws ANN. $\$ \S 10-3-1$ to $-3-20$ (1956) ; WASH. Rev. Cone $\$ \$ 7.04 .010-.220$ (1956); and Wrs. Stat. $\$ \S 298.01-18$ (1957).

7. 9 U.S.C. $\$ \$ 1-14$ (19.58). Before the enactment of this statute, the federal "common law" of arbitration was held to be that agreements to submit future disputes to arbitration were revocable and unenforceable. United States Asphalt Ref. Co. v. Trinidad Lake Petroleum Co., 222 Fed. 1006 (S.D.N.Y. 1915).

8. 9 U.S.C. $\$ 4$ (1958).

9. 9 U.S.C. $\$ 3$ (1958).

10. 9 U.S.C. $\& 9$ (1958).

11. The act applies only if the arbitral agreement involves "commerce," notwithstanding that the parties are properly in the federal court on some other basis of jurisdiction. Bernhardt v. Polygraphic Co. of America, 350 U.S. 198 (1956) (diversity); Zip Mfg. Co. v. Pep Mfg. Co., 44 F.2d 184 (D. Del. 1930) (patent law). The Act does not apply to contracts of employment of workers engaged in foreign or interstate commerce, 9 U.S.C. $\$ 1$ (1958), but collective bargaining agreements have been held to fall outside the scope of this exclusionary clause. Local 205, UEW v. General Elec. Co., 233 F.2d 85 (1st Cir. 1956), aff'd on other grounds, 353 U.S. 547 (1957).

See Kochery, The Enforcement of Arbitration Agreements in the Federal Courts: Erie v. Tompkins, 39 CorNenL L.Q. 74 (1953); Sturges \& Murphy, Some Confusing Matters Relating to Arbitration Under the United States Arbitration Act, 17 LAw \& CONTEMP. Prob. 580 (1952).

12. The Act does not create federal subject-matter jurisdiction. Therefore, a party desiring to invoke the Act must also satisfy the jurisdictional amount of $\$ 10,000$ and allege either diversity of citizenship or some other basis of federal subject-matter jurisdiction. Judge Hand summarized the limitations in Krauss Bros. Lumber Co. v. Louis Bossert \& Sons, 62 F.2d 1004, 1006 (2d Cir. 1933):

The remedy is not even co-extensive with the jurisdiction. For instance, the controversy may arise between citizens of different states and the contract not "involve commerce." A citizen of New Jersey may enforce arbitration against a citizen of New York upon a contract which requires him to ship the goods from Newark to 
The businessman doing business in several countries has an additional reason for preferring arbitration to local judicial remedies-the fear of discrimination against the foreigner, consciously felt in actual bias or unconsciously exhibited by preference for local principles of law. To avoid this prejudice, contracting parties have attempted to provide in their agreements that disputes arising should be settled by arbitration in a specified nation or by a specified impartial third party. Private organizations such as the American Arbitration Association and the International Chamber of Commerce have developed efficient arbitral procedures and make their services available to private parties. But some nations refuse to honor arbitral agreements calling for arbitration to be held in another country. ${ }^{13}$ Other nations refuse to enforce the arbitral agreement if litigation has been instituted in a local court before issuance of a final award. ${ }^{14}$ Further, the fate of foreign awards in the national courts has been less than encouraging to the merchant who seeks predictability of result. In some nations, the discrimination against foreign awards takes the root of requiring a full lawsuit upon the award and its underlying agreement, ${ }^{15}$ few nations treat foreign awards on a par with domestic awards. Past attempts to achieve equality of treatment by treaty, whether bilateral or multilateral, have been less than satisfactory. It is into this context that the United Nations Convention on the Recognition and Enforcement of Foreign Arbitral Awards has been introduced. ${ }^{16}$

\section{International Arbitration \\ The Bilateral Approach ${ }^{17}$}

The representatives of two nations may attempt to work out their differences over arbitration. The goal under this approach is a uniform set of procedures in the courts of both nations equally applicable to foreign and domestic arbitral agreements and awards. Often the best that can be accomplished, however, is a declaration of non-discrimination against foreign awards. Since World War II, the United States has been developing the use of a commercial arbitration clause in its bilateral Treaties of Friendship, Commerce and Navigation.

The arbitration clause in the first such treaty, entered into with China in 1946 , provided that an agreement for arbitration would be given full faith and

Manhattan, but not upon one where they are to go from Manhattan, to the Bronx. Conversely, a citizen of New York may not come to the District Court to enforce arbitration against another citizen of that state, though the goods must be shipped across a state line.

13. E.g., Uruguay. 2 Sanders, International Commercial Arbitration 75 (1960).

14. E.g., Italy. 1 SANDERS, op. cit. supra note 13, at 349.

15. Apparently the Philippine practice, cf. Espego, The Enforcement of American Azvards in the Philippines, 13 ARB. J. (n.s.) 150 (1958).

16. U.N. Doc. No. E/CoNf. 26/9/Rev. 1 (1958).

17. For a review of arbitration clauses in recent United States treaties, see Walker, Commercial Arbitration in United States Treaties, 11 ARs. J. (n.s.) 68 (1956), and Walker, United States Treaty Policy on Commercial Arbitration, in Domke 49. 
credit in the courts of either nation, but that an award would be recognized only in the nation in which it was rendered: 18

... In the case of any controversy susceptible of settlement by arbitration, which involves nationals, corporations or associations of both High Contracting Parties and is covered by a written agreement for arbitration, such agreement shall be accorded full faith and credit by the courts within the territories of each High Contracting Party, and the award or decision of the arbitrators shall be accorded full faith and credit by the courts within the territories of the High Contracting Party in which it was rendered, provided the arbitration -proceedings were conducted in good faith and in conformity with the agreement for arbitration.

In the next two treaties, with Italy ${ }^{19}$ in 1948 and Uruguay ${ }^{20}$ in 1949 , no provision for commercial arbitration was included. The 1950 Treaty with Ireland contains an arbitration clause quite different from that in the Treaty with China. This Treaty more satisfactorily covers the important subject of enforcement of foreign awards: ${ }^{21}$

Contracts entered into between nationals and companies of either Party and nationals and companies of the other Party, that provide for the settlement by arbitration of controversies, shall not be deemed unenforceable within the territories of such other Party merely on the grounds that the place designated for the arbitration proceedings is outside such territories or that the nationality of one or more of the arbitrators is not that of such other Party. No award duly rendered pursuant to any such contract, and final and enforceable under the laws of the place where rendered, shall be deemed invalid or denied effective means of enforcement within the territories of either Party merely on the grounds that the place where such award was rendered is outside such territories or that the nationality of one or more of the arbitrators is not that of such Party.

This clause introduces the minimal prohibition against denying effect to an agreement or award merely because it contains an "alien" element. Moreover, it extends the concept of reciprocity to awards involving arbitration physically held in the territory of neither Party. The subsequent treaties with Colombia, Denmark, Haiti, Israel, Italy, Nicaragua and Korea all followed this provision. ${ }^{22}$

18. Article VI, para. (4) (T.I.A.S. No. 1871).

19. 63 Stat. 2255 (1948).

20. Senate Ex. D., 81st Cong., 2d Sess. (1950).

21. Article X (T.I.A.S. No. 2155).

22. Colombia: Senate Ex. M., 82d Cong., 1st Sess. (1951); Denmark: Senate Ex. I, 82d Cong., 2d Sess. (1951); Haiti: Senate Ex. H, 84th Cong., 1st Sess. (1955) ; Israel: 5 U.S.T. \& O.I.A. 550, T.I.A.S. No. 2948 (1951) ; Italy: Senate Ex. H, 82d Cong., $2 d$ Sess. (1951) ; Nicaragua: 9 U.S.T. \& O.I.A. 449 (1956); and Korea: 8 U.S.T. \& O.I.A. 2217 (1957). This provision is also contained in a Convention of Establishment between the United States and France, signed at Paris, November 25, 1959, and in a Treaty of Friendship, Commerce and Navigation with Pakistan signed at Washington on November 12, 1959. Both were submitted to the Senate on April 6, 1960. 
The 1951 Treaty with Greece contains an arbitration clause designed better to adapt the concept of "national treatment" to a federal system:

... Awards duly rendered pursuant to any such contracts, which are final and enforceable under the laws of the place where rendered, shall be deemed conclusive in enforcement proceedings brought before the courts of competent jurisdiction of either Party, and shall be entitled to be declared enforceable by such courts, except where found contrary to public policy. When so declared, such awards shall be entitled to privileges and measures of enforcement appertaining to awards rendered locally. It is understood, however, that awards rendered outside the United States of America shall be entitled in any court in any State thereof only to the same measure of recognition as awards rendered in other States thereof. ${ }^{23}$

A similar clause was included in the recent treaties with Japan ${ }^{24}$ and Germany. ${ }^{25}$

The most positive formulation used by the United States appears in the 1956 Treaty with The Netherlands, which contains the following arbitration provision:

... (b) In conformity with subparagraphs (1) and (2) hereof, awards duly rendered pursuant to any such contracts, which are final and enforceable under the laws of the place where rendered, shall be deemed conclusive in enforcement proceedings brought before the courts of competent jurisdiction of either Party. (1) As regards recognition and enforcement in the United States of America, such awards shall be entitled in any court in any State thereof only to the same measure of recognition and enforcement as awards rendered in other States thereof. (2) As regards enforcement in the Kingdom of the Netherlands, such awards shall be dealt with in the same way as awards as referred to in the Convention on the execution of foreign arbitral awards concluded at Geneva on September $26,1927 .{ }^{26}$

The Netherlands treaty goes beyond the principle of non-discrimination and makes proper foreign awards "conclusive" in the courts of either country. It bars an investigation by the enforcing court of the correctness of the arbitrator's findings of fact and conclusions of law. However, these awards are granted no better procedures than domestic awards, and are still subject to the public policy of the local court. Only the public policy of distrusting foreign awards has been eliminated.

The advantage of the bilateral approach is that it facilitates the conclusion of an arbitration treaty at any time, regardless of the stage of development of local arbitration procedures. Moreover, it leaves each country free to experiment with its internal arbitral procedures, automatically incorporating under

23. Article VI(2) (T.I.A.S. No. 3057). The failure of this clause to limit enforcement to those awards which would otherwise satisfy the Federal Arbitration Act may have the effect of overriding the limitations in that Act.

24. Japan: 4 U.S.T. \& O.I.A. 2063, T.I.A.S. No. 2863 (1953).

25. Germany: 7 U.S.T. \& O.I.A. 1839, T.I.A.S. No. 3593 (1954).

26. Article V, para. 2 (T.I.A.S. No. 3942). Cf. note 23 supra. 
the treaty any improvements made in local arbitration procedures. The special status of arbitration in each of the two countries can be easily taken into account, thus avoiding the "least common denominator" factor necessary in a multilateral treaty.

The disadvantages of the bilateral approach lie in the disparity in the scope and in the dispositive provisions of such treaties, and in the slow pace at which the treaties are being negotiated and ratified. While bilateral treaties could conceivably be the preferred mechanism for change, to date they have not been effective. In part, this is because they have tended merely to incorporate the existing law of the two nations rather than to evolve a uniform, albeit new, law.

\section{The Multilateral Approach}

To avoid the disadvantages of the bilateral approach, some proponents of international commercial arbitration have turned to the use of multilateral conventions. The most ambitious attempt along these lines resulted in the "Geneva Treaties"- the 1923 Protocol on Arbitration Clauses and the 1927 Convention on the Execution of Foreign Arbitral Awards. ${ }^{27}$ Efforts to enact a multilateral convention on arbitration were made as early as 1904, and were intensified after World War I through the mechanism of the League of Nations. ${ }^{28}$ It was under the auspices of the League that the Protocol on Arbitral Clauses was adopted in Geneva in 1923. Under this Protocol, each Contracting State "recognizes the validity" of certain arbitral agreements, whether relating to existing or future differences, and agrees that its courts, if invoked in defiance of such an agreement, will refer the parties to the decision of the arbitrators.

The Geneva Protocol was followed by the 1927 Geneva Convention on the Execution of Foreign Arbitral Awards. In effect, in order to qualify for enforcement under the Geneva Convention, awards must arise from arbitration agreements covered by the Geneva Protocol; they must be made in one of the contracting States and must concern disputes between nationals of contracting States.

There are certain positive tests which each award must meet in order to qualify. It must arise from a valid arbitration agreement, it must deal with a legally arbitral dispute, it must have been handed down by a properly constituted tribunal and in conformity with the local procedural law, it must be final in the country where made, and it must not violate the public policy of the country where enforcement is sought. Even though these tests are satisfied, the enforcing court may on its own motion refuse enforcement if it is satisfied that the award has been annulled or that it resulted from defective procedures. Although the Geneva Convention fails to fix the burden of proof on these tests,

27. The text of the Protocol is reprinted in 2 Hudson, International Legislation 1062-65 and the Convention in 3 Hudson, International Legrslation 2153-60 (1932).

28. The background of the Geneva treaties is outlined in Nussbaum, Treaties an Commercial Arbitration-A Test of International Private-Laze Legislation, 56 HARv. L. Rev. $219,220-22$ (1942). 
most of them are of such a nature that the burden is on the plaintiff who has obtained an award. The defendant who is seeking to block enforcement of the award need disprove or rebut only one of the various tests to be successful.

The Geneva Treaties were not self-executing and, therefore, supplementary national legislation by the contracting States was required. ${ }^{29}$ The legislation enacted varied from country to country and left some doubt as to the extent to which the signatory states actually carried out their obligations under the treaties. For example, France and Poland incorporated the principles of the Protocol into their general law, while Sweden so incorporated the principles of both the Protocol and the Convention. Under the Swiss Constitution, ratification and promulgation of the treaties were sufficient to make the treaties domestic law. The treaties were transformed into internal law by legislation in Belgium, Estonia, Greece, England, India, Italy and The Netherlands. Estonia, France, Greece and The Netherlands limited the treaties to commercial matters.

The Geneva treaties have not produced the widespread international enforcement of arbitration agreements and awards which was expected of them. The primary blame for this failure appears to lie with the structure of the treaties themselves. By effectively placing the burden of proof on every issue upon the successful party, the treaties have eased the path of the defaulting defendant and the partial tribunal.

An additional criticism of the treaties has been leveled at the diversity-ofcitizenship requirement; the treaties apply to differences between parties "subject respectively to the jurisdiction of different Contracting States." The uncertainty engendered by this limitation is compounded by the varying national theories concerning the elements of nationality.

\section{The Present Status of Foreign Arbitral Agreements and Awards}

Against this background of differing national policies, bilateral treaties and multilateral conventions, it is not too surprising that the fate of any given international arbitral agreement or award is uncertain. The crucial factor in any controversy will be that of jurisdiction. The court of the country first obtaining jurisdiction will apply its own national policy, within the limitations of its international obligations, to an international arbitral agreement or award brought before it. In order to assess the advantages to be gained by accession to the United Nations Convention, a look at the present status of arbitration agreements and awards is in order. ${ }^{30}$

29. A survey of the supplementary legislation enacted is contained in Nussbaum. Id. at $222-24$.

30. See generally Domke at 21, 42,57,118; Blom-Cooper, Enforcement of Foreign Awards in England, 9 ARB. J. (n.s.) 198 (1954); Domke, On the Enforcement Abroad of American Arbitration Awards, 17 LaW \& Contemp. Prob. 545 (1952); Domke, Enforcement of Foreign Arbitral Awards in the United States, 13 ARB. J. (n.s.) 91 (1958); Ansay, Commercial Arbitration in Turkey, 12 ARB. J. (n.s.) 31, 34-37 (1957) ; Holley, Enforcement of American Awards in France, 14 ARB. J. (n.s.) 83 (1959); Domke, Mendelson, 


\section{Specific Performance and Stays of Litigation}

On the state level in the United States the question of specifically enforcing the arbitral clause through court stays or court orders is left to the discretion of each state's legislature. In those states with modern arbitration statutes, provision is generally made both for court stays and specific performance of the arbitration clause. In states which retain the common law doctrine of revocability of arbitration clauses as to future disputes, neither remedy is open to the party seeking to enforce the arbitration clause. The potential effectiveness of Robert Lawrence Co. v. Devonshire Fabrics ${ }^{31}$ should be noted here. This case held that arbitration agreements governed by the federal act "previously held by state law to be invalid, revocable or unenforceable are now made 'valid, irrevocable and enforceable.' This is a declaration of national law equally applicable in state or federal courts."32 If that case is followed, then

\& Rathkopf, Foreign Trade Arbitration in American Courts, 13 ARB. J. (n.s.) 30 (1958) ; Philip, Commercial Arbitration in Denmark, 13 ARE. J. (n.s.) 16, 18-22 (1958); Bansal, The Practice of Commercial Arbitration in India, 13 ARB. J. (n.s.) 23 (1958) ; Espejo, The Enforcement of American Awards in the Philippines, 13 ARB. J. (n.s.) 150 (1958).

31. 271 F.2d 402 (2d Cir. 1959), cert. granted, 362 U.S. 909 (1960); Note, 69 Y YLE L.J. 847 (1960).

32. Id. at 407. The District Court had denied defendant's motion to stay judicial proceedings pending arbitration, on the ground that fraud in the inducement vitiates the agreement to arbitrate. Reversing, the Court of Appeals held that federal law (the Federal Arbitration Act) governed the validity and interpretation of the contract, and that federal law sanctioned an agreement to arbitrate any dispute, including a claim of fraud in the inducement. The Court admitted that New York law (fraud in the inducement is not arbitrable), had it governed this New York contract involving interstate commerce, would have produced a different result.

The Court held that the Federal Arbitration Act not only removed the common law ban on enforcing "future disputes" agreements, but also directed the federal courts to develop "principles of federal substantive law" with respect to the validity and interpretation of interstate arbitration agreements. This broad holding is at variance with the following three federal cases:

American Airlines v. Lotuisville \& Jefferson County Air Bd., 269 F.2d 811 (6th Cir. 1959) : Federal Arbitration Act merely removes common law ban on enforcing valid arbitration contracts; invalidity of the contract for other reasons, e.g., fraud, lack of consideration or capacity or authority to contract, is still governed by the applicable substantive law of contracts, state or federal; plaintiff administrative board, as a matter of Kentucky law, had no authority to enter contract providing for the fixing of airport rental fees by arbitration.

Ross v. Twentieth Century-Fox Film Corp., 236 F.2d 632, 634 (9th Cir. 1956) : "Next, it is argued that, even if this contract is the sort contemplated by Section 3 of Title 9 [U.S.C.], the interpretation of the contract is still a matter of California law, and it must be determined by reference to that law whether the contract contains language which amounts to a provision for arbitration. We think that this is a correct analysis supported by Bernhardt v. Polygraphic Co. of America."

Commonwealth Oil Ref. Co. v. Lummus Co., 174 F. Supp. 485,175 F. Supp. 873 (D.P.R. 1959), vacated, 280 F.2d 915 (1st Cir. 1960). The District Court held that the Puerto Rican Arbitration Act governed a contract involving interstate commerce. The Court of Appeals did not pass on the issue, but specifically questioned the Lavence case. 
arbitration clauses contained in contracts evidencing transactions in foreign commerce are, as a matter of federal substantive law, valid and irrevocable whether litigated in a state or a federal court. Whether a state court could merely give damages for breach of the clause while withholding specific performance is yet to be decided.

On the federal level, sections 3 and 4 of the Federal Arbitration Act are designed to allow enforcement of arbitral clauses in contracts involving foreign commerce. But these sections are limited. Section 3 provides for a stay of court proceedings in defiance of an arbitration clause, but only by "the court in which such suit is pending." Section 4's provisions for specific performance of the arbitral clause are available in "any court of the United States which, save for such agreement, would have jurisdiction." Thus the availability of section 4 is circumscribed by the requirement of in personam jurisdiction and jurisdiction over the subject matter. The latter requirement involves finding another basis for federal jurisdiction, either under the diversity-of-citizenship clause or other federal subject-matter jurisdictions.

With regard to the enforceability of arbitration clauses abroad, the answer varies from country to country, and is controlled both by each country's national law and also by the obligations it has incurred by multilateral and bilateral treaties. ${ }^{33}$

\section{Enforcement of Arbitral Awards}

Once the arbitration has terminated in an award, the successful party desires to enforce it with minimal procedural delay. In the United States, no state arbitration statute makes any provision for the enforcement of foreign arbitral awards ${ }^{34}$ therefore, there is no summary procedure to confirm an interstate or foreign award in the state courts. This is true even as to those countries with whom the United States has recently concluded treaties dealing with commercial arbitration, since such treaties entitle foreign awards to no better treatment than interstate awards. ${ }^{35}$ In some states, however, the more cumbersome procedure of suing upon the foreign award in state courts can achieve surprisingly vigorous enforcement. In Gilbert $v$. Burnstine, ${ }^{36}$ for example, a British

33. Between countries that ratified the Geneva Protocol of 1923 , supra note 27 , at $1063-64 ; \S 4$ of that document requires:

The tribunals of the Contracting Parties, on being seized of a dispute regarding a contract made between persons to whom Article 1 applies and including an Arbitration Agreement whether referring to present or future differences which is valid in virtue of the said article and capable of being carried into effect, shall refer the Parties on the application of either of them to the decision of the Arbitrators.

34. Domke, Enforcenent of Foreign Arbitral Awards in the United States, 13 ARB. J. (n.s.) 91, 92 (1958); but see note 23 supra.

35. Although an interstate award reduced to judgment in the state of rendering must be given full faith and credit in the other states, a foreign award reduced to judgment in a foreign country is entitled to no such constitutional protection.

36. 255 N.Y. 348,174 N.E. 706 (1931). 
arbitral award was held enforceable against a New York defendant even though he had never appeared nor been served within the territory of the United Kingdom. The New York court held that the arbitration agreement constituted a submission to the British Arbitration Act and to the jurisdiction of the British courts for the enforcement of the agreement. ${ }^{37}$

The Federal Arbitration Act is of little use with regard to enforcement of a foreign award in a federal court unless the arbitral agreement specifies a court in which an order conforming the award may be made. The Act provides :

If no court is specified in the agreement of the parties, then such application may be made to the United States Court in and for the district within which such award was made. ${ }^{38}$

Thus the successful party must, if he uses the federal courts, bring a common law action upon the award, alleging some further basis of federal jurisdiction. ${ }^{30}$

With regard to enforcing foreign arbitral awards abroad, the answer again varies with the national law of the countries involved and their status as parties or non-parties to the Geneva Convention of 1927. The Geneva Convention requires enforcement of awards rendered between nationals of the signers according to local procedural rules. The actual effectiveness of the obligation incurred under the Geneva Convention thus depends on the supplementary national legislation. ${ }^{40}$ Between nonparties to the Geneva Convention, there is little uniformity. ${ }^{41}$ Enforcement of an award rendered and reduced to judg-

37. The principle of this decision has since been incorporated into $\$ 1450$ of the New York Civil Practice Act, which provides that the making of a contract providing for arbitration in New York "shall be deemed a consent of the parties thereto to the jurisdiction of the Supreme Court of this state to enforce such contract or submission and to enter judgment on an award thereon." The constitutionality of this provision is challenged in Weiss, The Arbitration Award and the Non-Resident: Nuance in New York, 48 Colum. L. Rev. 366 (1948).

38. 9 U.S.C. $\$ 9$ (1952).

39. E.g., Standard Magnesium Corp. v. Otto Fuchs, 251 F.2d 455 (10th Cir. 1957). The plaintiff brought suit in a federal district court upon a Norwegian award rendered ex parte according to the arbitration rules of the International Chamber of Commerce. The defendant claimed that the Federal Arbitration Act did not provide for such an award or such a suit, since no order to proceed with arbitration under $\$ 4$ had been made in the case. This defense was rejected and judgment entered for the plaintiff, the court holding that the invoking of $\S 4$ was permissive and unnecessary where the parties had agreed in advance to ex parte arbitration.

40. For example, the United Kingdom legislation adds a concept of reciprocity to the conditions for enforcing Geneva awards. A foreign award rendered pursuant to an arbitral agreement to which the Geneva Protocol applies is granted the same treatment as a domestic British judgment if the award is between nationals of such contracting parties and within such territories as the Crown may, on being satisfied that reciprocal provisions exist, declare to be Parties and territories to which the Geneva Convention applies. Arbitration Act, 1950, 14 Geo. 6, c. 27, § 35 .

41. In the United Kingdom, for example, commentators have disagreed as to the enforceability of an award rendered in a country not a party to the Geneva Convention. 
ment in New York was denied by the Supreme Court of Portugal..2 On the other hand, the Supreme Court of Colombia granted execution upon a New York judgment based upon a New York award. ${ }^{43}$

\section{The United Nations Convention of 1958 Background ${ }^{44}$}

Soon after the establishment of the United Nations after World War II, attempts were made to work out a multilateral solution to the problem of enforcing foreign arbitral awards. In 1953 the International Chamber of Commerce requested the Economic and Social Council of the United Nations to conclude a Convention on the subject. On April 6, 1954, the Council established an Ad Hoc Committee to study the Convention proposed by the International Chamber of Commerce. ${ }^{45}$ This Ad Hoc Committee considered the proposed Convention and eventually produced a Draft Convention of its own, ${ }^{46}$ which was submitted to various member and nonmember countries and also to interested nongovernmental organizations for their comments. These comments were submitted in the Secretary General's report to the Economic and Social Council. ${ }^{47}$

The Council decided to call a conference for the conclusion of a convention on the recognition and enforcement of foreign arbitral awards and, further, "to consider, if time permits, other possible measures for increasing the effectiveness of arbitration in the settlement of private law disputes and to make such recommendations as it may deem desirable." 48 The Conference convened from May 20 to June 10,1958, attended by representatives of 45 nations including

Schmitthof states that a foreign award creates a new obligation only if it has the status of a judgment in the country where rendered and that, if the award does not so qualify, the successful party should bring suit on the original cause of action. ScHMitTHOF, ENGis Conflicts of Laws 47-49 (3d ed. 1954); accord, Dicey, Conflict of Laws 433 (6th ed. 1949). On the other hand, it is argued that a foreign arbitration award is in no sense assimilable to a foreign judgment and that, in suing upon a foreign award, the plaintiff bases his action upon the agreement to arbitrate, the original cause of action having been extinguished by the award. Blom-Cooper, Enforcement of Foreign Awards in England, 9 ARB. J. (n.s.) 198 (1954).

42. Edmond Weil, Inc. v. Sociedade Industriale E Mercantil dos Olivias, Lda., S. Ct. of Justice, Portugal, No. 53194 (Nov. 5, 1946). A Portuguese statute was held to require litigation of the controversy in the Portuguese courts. Arbitration abroad of the dispute was thus prohibited and the suit, based upon a New York judgment, was dismissed.

43. Hide Trading Corp. v. Field Echenique Compania, Ltda., S. Ct. of Justice, Colombia, Gaceta Judicial Tomo, 68 No. 2087-88, at 139 (1951), translated in 6 ARB. J. (n.s.) 159 (1951).

44. For a brief summary of events leading up to the U.N. Convention, see Note, 53 Am. J. INT'L L. 414 (1959).

45. U.N. Economic and Social Council Res. No. 520 (XVII), 17th Sess., U.N. Economic \& Social Council Off. Rec., Supp. No. 1.

46. U.N. Doc. No. E/AC 42/SR.10/3 (1955).

47. U.N. Doc. No. E/2822 (1956) and addenda 1 to 6.

48. U.N. Economic and Social Council Resolution No. 604 (XXI), 21st Sess., U.N. Economics \& Social Council Off. Rec., Supp. No. 1 (1956). 
the United States and Soviet Russia. Three intergovernmental organizations and ten nongovernmental organizations also took part. On June 10, in its Final Act, ${ }^{49}$ the Conference adopted the Convention which it had drafted, and also made several recommendations ${ }^{50}$ to the Economic and Social Council for further measures needed to increase the effectiveness of arbitration in the settlement of private law disputes.

Ten nations signed the Convention on June 10, 1958, and 13 more nations signed it within the period open for signature-until December 31, 1958.

Pursuant to Article I of the Convention, Morocco, France, Czechoslovakia, India, USSR, Byelorussian SSR, and Ukrainian SSR limited their ratification to awards made in the territory of other contracting states, and France and India limited their ratification to differences deemed "commercial" under their national law. Pursuant to Article X, France extended its accession to all territories included in the French Republic.

\section{Provisions}

The President of the Conference summarizes the anticipated advantages of the Convention as follows:

... it was already apparent that the document represented an improvement on the Geneva Convention of 1927. It gave a wider definition of the awards to which the Convention applied; it reduced and simplified the requirements with which the party seeking recognition or enforcement of an award would have to comply; it placed the burden of proof on the party against whom recognition or enforcement was invoked; it gave the parties greater freedom in the choice of the arbitral authority and of the arbitration procedure; it gave the authority before which the award was sought to be relied upon the right to order the party opposing the enforcement to give suitable security. ${ }^{51}$

\section{Coverage}

The Convention applies to all awards made in the territory of a State "other than the State where the recognition and enforcement of such awards are sought" and also to awards "not considered as domestic awards in the State where their recognition and enforcement are sought." 22 This definition includes

49. U.N. Doc. No. E/Conf. 26/9/Rev. 1, of June 10, 1958.

50. The discussion of these other matters and recommendations in connection therewith are summarized in the Official Report of the United States Delegation to the United Nations Conference on International Commercial Arbitration 16-17, 25-27 (August 15, 1958) [hereinafter cited as U.S. DEx. REp.].

51. U.N. Doc. No. E/Conf. 26/SR.25, at 2 (1958). See generally Contini, International Conmercial Arbitration-The United Nations Convention on the Recognition and Enforcement of Foreign Arbitral Awards, 8 AMr. J. CoMr. L. 283 (1959); Pisar, The United Nations Convention on Foreign Arbitral Awards, 33 So. CAL. L. Rev. 14 (1959); Sultan, The United Nations Arbitration Convention and United States Policy, 53 Ax. J. INT'x L. 807 (1959).

52. Article $I$. The legislative history of this and other articles in the Convention is summarized in Haight, Convention on the Recognition and Enforcement of Foreign Awards (1958) [hereinafter cited as HaIGET]; U.S. DeL. Rep. 
the territorial concept and special local definitions of "domestic," such as the French position that an award made in France under foreign law is regarded as a non-domestic award. The non-domestic criterion is not a limitation on the territorial test. The Convention applies to all awards rendered outside the enforcing State and to awards rendered inside the enforcing State if that State does not regard the award as domestic. ${ }^{53}$ The Convention is not limited to commercial disputes, but applies explicitly to any award not considered domestic by the nation where enforcement is sought. There is no diversity of citizenship clause. The Convention applies to awards "arising out of differences between persons, whether physical or legal," and thus appears to cover nations in their commercial relationships. It also applies to awards made by permanent arbitral bodies, a provision which covers arbitration before trade tribunals of Communist countries. ${ }^{\text {.4 }}$

\section{Reservations}

Notwithstanding the breadth of the coverage provisions, Article I(3) of the Convention provides that any nation may "on the basis of reciprocity" declare that it will apply the Convention to awards made only in the territory of another Contracting State, ${ }^{55}$ or that it will apply the Convention only to differences arising out of legal relationships "considered as commercial under the national law of the State making such declaration."56 These possible limitations-the exclusion of awards rendered in the territory of the declarant or in the territory of a noncontracting nation, and of noncommercial disputesare relatively unimportant. They were inserted for the benefit of countries like Belgium whose arbitration law is limited to commercial matters, and for the benefit of territorially-minded countries. What is important is the principle of allowing reservations.

Israel and several other nations had argued for unlimited reservations;

53. The Convention apparently also overrides the German policy that an award rendered anywhere under German Procedural law is a domestic German award and the Italian position that any award between Italians is domestic. This extension was agreed to when the delegates expected that reservations on this subject would be allowed, but the final draft of the Convention omitted such reservations. U.S. DEL. REP. 6, 11-12.

54. But cf. U.S. DEL. REP. 6:

It is definitely understood, however, that the convention applies only to awards resulting from arbitrations to which the parties have submitted voluntarily. If the arbitration were conducted by a permanent body to which the parties are obligated to refer their disputes regardless of their will, the proceedings are judicial rather than arbitral in character and the resulting award consequently would not come within the purview of the convention.

55. This language seems to allow a State to undercut the "non-domestic" provision of Article I(1) by reserving awards rendered in the territory of the declarant.

56. See U.S. Dez. Rep. 7:

The phrase "legal relationships whether contractual or not" is employed to assure coverage not only for disputes arising under commercial contracts but for other disputes, such as damage claims, which might come within the scope of the commercial code. 
Japan and the U.S.S.R. argued for no reservations at all. Both extremes were rejected..$^{57}$ As a compromise the phrase "on the basis of reciprocity" was inserted in the first sentence of Article I(3). The effect of this phrase is not at all clear, however. It may mean that the power to limit application of the Convention to territorial awards is contingent upon a reciprocal reservation by another contracting party. But which party? Would one suffice? Or it may mean that any state may freely impose the reservation, but at the price of losing the power to enforce abroad whatever awards in the other it refuses to enforce itself. This final interpretation would render the clause superfluous, however, for such reciprocal nonenforcement is already provided for in the broad reciprocity clause in Article XIV.

The second reservation-to commercial differences (presumably the application of both Article II as to agreements and Article I as to awards are meant to be covered by "differences") -is not literally qualified by "on the basis of reciprocity." That this was to be an unqualified power to limit application of the Convention to commercial differences seems evident from the fact that it was inserted at the insistence of Belgium, which stated it could not accede to the Convention without such a reservation. ${ }^{58}$

The intent of some delegates to curtail further reservations was expressed in Section 14 of the Final Act of the Conference:

14. The Conference decided that, without prejudice to the provisions of its Articles I(3), X, XI and XIV, no reservations shall be admissible to the "Convention on Recognition and Enforcement of Foreign Arbitral Awards." 59

But this intent was not unanimous. For example, the delegate of Israel declared that his delegation would sign the Convention "without prejudice to its attitude on the admissibility of reservations under the general principles of public international law."60 The possibility of an accession being held void because of an attempted reservation is slim, but cannot be disregarded. ${ }^{61}$

\section{Recognition of Arbitral Agreements}

Article II(1) requires each State to "recognize" agreements in writing, to submit to arbitration past or future differences arising between the parties

57. HATGHT 13.

58. U.N. Doc. No. E/Conf. 26/L. 63, at 7 (1958) ; HaIGHT 16.

59. U.N. Doc. No. E/Conr. 26/9/Rev. 1, at 4 (1958).

60. U.N. Doc. No. E/Conf. 26/SR.24, at 12 (1958); HAIGHT 17.

61. Cf. The Advisory Opinion of the International Court of Justice in Reservations to the Genocide Convention, [1951] I.C.J. Rep. 15 (".. it is the compatability of a reservation with the object and purpose of the convention that must furnish the criterion ... of membership.").

62. With respect to the requirement that the agreement be in writing, Article II(2) provides:

The term "agreement in writing" shall include an arbitral clause in a contract or an arbitration agreement, signed by the parties or contained in an exchange of letters or telegrams. 
"in respect of a defined legal relationship, whether contractual or not, concerning a subject matter capable of settlement by arbitration."

This extraordinary provision has many facets. Most notably, it makes no attempt to define the kinds of agreements which Contracting States are required to recognize. There are no words indicating that the arbitral agreements meant are those with a foreign or "non-domestic" element. Despite the constant insistence of the German delegate that the arbitral agreements be related to an arbitral award capable of enforcement under the Convention, ${ }^{63}$ the Conference adopted the Article without any words so linking the agreements to the awards covered by Article III. ${ }^{64}$

Furthermore, the words "and enforce," so prominent in Article I and Article III, are absent from Article II. Sweden introduced Article II (1) in an attempt to re-enact the first article of the Geneva protocol which required member States to "recognize the validity" of arbitral agreements. ${ }^{65}$ The Conference debated whether the Economic and Social Council Resolution calling the Conference authorized it to deal at all with agreements, and was finally convinced by the United Kingdom delegate that a Convention on awards with no provision recognizing the underlying arbitral agreement would be too easily nullified. ${ }^{66}$ Several of the delegates felt that this Article would undercut the provisions on awards, since courts would be required "to treat as valid an agreement resulting in an arbitral award that could not be enforced under Article IV (1) of the Convention."'67 This argument, based on the Convention's failure to restrict the agreements to those concerning awards enforceable under Articles I and III, was instrumental in causing the deletion of the words "as valid" after "recognize." 68 Whatever "recognize" may now mean, after that debate, it

63. HAIGHT 27.

64. Cf. U.S. DeL. Rep. 19:

Its language is such as to extend the treaty rule to purely domestic contracts as well.

The similar failure to limit the stay provisions of $\$ 3$ of the Federal Arbitration Act to those arbitration agreements evidencing "a transaction involving commerce" within the meaning of $\S 2$ of the Act created a split of opinion among the federal courts over the issue whether $\S 3$ stood on its own footing which was not resolved until Bernhardt v. Polygraphic Co. of America, 350 U.S. 198, 201 (1956) held $\S 3$ limited by $\S 2$.

65. Article I of the Geneva Protocol provides:

Each of the Contracting States recognizes the validity of an agreement whether relating to existing or future differences between parties subject respectively to the jurisdiction of different Contracting States by which the parties to a contract agree to submit to arbitration all or any differences that may arise in connection with such contracts relating to commercial matters or to any other matter capable of settlement by arbitration, whether or not the arbitration is to take place in a country to whose jurisdiction none of the parties is subject.

The text of the Protocol is reprinted in 2 Hudson, Internatronal Legislation 1062-65.

66. HATGHT 25.

67. U.N. Doc. No. E/CoNF. 26/SR.21, at 19-20 (1958).

68. HaIGHT 25. 
seems clear that it does not require a Contracting State to grant specific performance of the agreement by ordering a recalcitrant party to arbitrate.

Finally, Article II(1) is limited to arbitration of differences concerning a subject matter "capable of settlement by arbitration." This phrase endows the courts of the forum State with authority to decide the "arbitrability" of disputes. $^{69}$ Considerable latitude is thus afforded the tribunal deciding the issue of arbitrability, and to that extent the predictability of result under the Convention is weakened. Presumably, this determination is to be made upon the basis of the law to which the parties have subjected their agreement. Failing such a designation, arbitrability might be decided by the law of the State where the agreement was signed, where the dispute arose or where the agreement is sought to be enforced. ${ }^{70}$

\section{Stay of Litigation}

Article II(3) requires a court of a Contracting State, "when seized of an action in a matter" involving an arbitral agreement, to refer the parties to arbitration, "unless it finds that the said agreement is null and void, inoperative or incapable of being performed."

The article does not explicitly relate arbitral agreements which will be the basis for a stay order to arbitral awards capable of enforcement under the Convention. Such a limitation should be implied, however, since the only justification for the stay is the necessity of protecting awards capable of enforcement. A more serious omission is the absence of any provision defining the law which governs the issue whether the arbitral agreement is "null and void, inoperative or incapable of being performed." Presumably, the law specified by the parties in their agreement should govern. Absent such a specification, the forum State might look to its own law and policy, or to the law of the place of execution of the agreement, or to the law of the place where the dispute arose. ${ }^{71}$

\section{Enforcement of Foreign Arbitral Awards-the Basic Obligation}

Article III requires each Contracting State "to recognize arbitral awards as binding" and to enforce them in accordance with the rules of procedure of the

69. For a review of the problems created by vesting this power in the judiciary, see Kharas \& Koretz, Judicial Determination of the Avbitrable Issue, 11 ARB. J. (n.s.) 135 (1956).

70. The corresponding provision with regard to awards in Article V 2.(a) relegates the issue of the arbitrability of the subject matter of the dispute to determination under the law of the country where enforcement of the award is sought. It can be expected that the courts of the State where recognition of the agreement is sought will adopt a similar standard of judging the arbitrability of the dispute under the law of the forum.

71. The corresponding provision in Article V 2.(b) allows the forum State to refuse enforcement of an award if the recognition and enforcement of the award would be contrary to its public policy. It can be expected that the forum State will similarly refuse to stay litigation or to order the parties to arbitration where its public policy renders the arbitral agreement "null and void, inoperative or incapable of being performed." 
forum State. The forum State must not impose "substantially more onerous conditions or higher fees or charges" on the recognition or enforcement of arbitral awards to which the Convention applies than it imposes on the recognition or enforcement of domestic arbitral awards. Unfortunately, this article, which defines the fundamental obligation imposed by the Convention, is imprecisely drafted.

The Conference again failed explicitly to limit the arbitral awards meant to those awards defined by Article I. The first sentence of Article III, standing alone, states an obligation on the part of Contracting States to recognize and enforce all arbitral awards, foreign or domestic. That the delegates meant to limit this sentence to Article I awards is the reading suggested by the statements of various delegates.

The drafting of this Article was complicated by the desires of some delegates to institute a uniform system of international procedural rules of enforcement for foreign awards. While this goal would increase the reliability of arbitral agreements, its achievement seemed premature in light of the widely divergent national attitudes toward arbitration. A counterproposal was made by Belgium that the same rules of local procedure be made applicable to foreign and domestic awards. The delegate from the United States supported this proposal, citing the success of the "principle of national treatment" in recent United States bilateral treaties. ${ }^{72}$ On the other hand, several States pointed out that their local procedures for enforcing foreign awards differed from those applicable to domestic awards; E1 Salvador and Sweden declared that their law required foreign awards to be submitted to the Court for a determination whether the requirements of relevant international instruments had been satisfied, while domestic awards are granted summary execution. ${ }^{73}$

Because the Belgian proposal was rejected, ${ }^{74}$ the Contracting States have been left free to establish different procedures for the recognition and enforcement of foreign awards and domestic awards, within the limits of the "substantially more onerous conditions" rule. The Contracting States do not have much discretion under this rule, however, as the legislative history suggests that any condition going beyond a reasonable method of ascertaining that the award is covered by the Convention- would be substantially more onerous.

A final problem of construction under Article III has to do with the effect to be given the foreign arbitral award. In some countries, domestic and foreign awards are equally unenforceable. Presumably the words "recognize . . . as binding and enforce them in accordance with the riles of procedure," under the conditions laid down in the Convention, changes the law of such . States as to foreign awards. $A$ nation with no procedure for enforcing domestic awards would presumably be réquired by Article III to provide some such procedure

72. See U.N. Doc. No. E/Conf. 26/SR.10, at 3 (1958).

73. HaIGHT 30-31.

74. U.N. Doc. No. E/Conf. 26/SR.11, at 5 (1958). The second sentence of Article III, which had been a proviso on the first, was then made a separate sentence to make clear that it is a separate obligation of the Contracting States. 
for foreign awards. In those countries where domestic awards are recognized, but given effect only as rebuttable presumptions of fact in a subsequent court proceeding, the effect of Article III is not so clear. Apparently such countries must grant a more "binding" effect to foreign awards, but the standard they must meet is not specified. The Convention forbids States to treat foreign awards substantially worse than they treat domestic awards, but it does not declare how much better they must treat foreign awards.

\section{Enforcement of Foreign Arbitral Awards-Proving the Award}

The U.N. Convention places the burden of proof on the issue of validity on the defendant. The proponent of the award is required only to supply the original or a certified copy of the award and the arbitral agreement. ${ }^{75}$ These establish a prima facie case, and the burden shifts to the defendant to establish the invalidity of the award on one of the grounds specified in Article V 1.

\section{Enforcement of Foreign Arbitral Awerds-Grounds for Refusal}

Article $\mathrm{V}$ lists five grounds upon which the award may be refused recognition and enforcement upon the request of the defendant, and two further grounds upon which the competent authority of the forum State may on its own motion refuse recognition and enforcement. Two important themes run through the seven grounds of invalidity. The first is that of ultimate judicial control over enforcement of the award, the problem of the "double exequatur." 76 The ultimate authority was placed in the enforcing State, but Article V 1. (e) allows the defendant to attack the award on the ground that it has not yet become binding or has been set aside or suspended by a competent authority "of the country in which, or under the law of which, that award was made." The second important theme is contractual autonomy. ${ }^{77}$ The representatives of the International Chamber of Commerce advocated a proposal which would allow the parties to select the law of any country to pick principles of decision to govern the arbitration without regard to such law. Only the first of these was accepted, and is reflected throughout Article V. Complete divorce of the arbitral process from the law of some State was thought to be too revolutionary a concept for a Convention which was intended to be ratified by a large number of nations. ${ }^{78}$

75. Article IV. See U.S. Dex. Rep. 19:

While this article does not raise major difficulties, its provisions appear to be contrary to a number of minor State statutory procedures for the filing of documents with the court before which enforcement proceedings are brought.

76. See generally HaIGHT 34-35, 39-44; U.S. DeL. REP. 14-16. Proposals were made that the award be subject to review only in the country where rendered, or only in the country where enforcement was sought, or both.

77. See Haight 36-37; U.S. Dei. Rep. 11-13, 17-19.

78. The reasons that the U.S. delegation opposed complete autonomy of the parties were given as follows:

Bearing in mind that parties seldom negotiate a contract in terms of equal bargaining power, free choice of the procedural law of arbitration could be detrimental to 
Article $V$ 1. (a): The Absence of a Valid Arbitration Agreement.

The parties to the agreement referred to in Article II were, under the law applicable to them, under some incapacity, or the said agreement is not valid under the law to which the parties have subjected it or, failing any indication thereon, under the law of the country where the award was made;

There should be no enforcement of an award against a party who never agreed to arbitrate. The Convention allows the enforcing State to examine the validity of the agreement, but only under the law which the parties have chosen. If the parties have made no choice of law, then the law of the State where the award was made governs. However, the capacity of the parties to contract is to be judged by "the law applicable to them." This provision allows the enforcing State to apply its Conflicts of Laws principles in arriving at the law governing the capacity of the parties. This provision, unlike Article II, contains no requirement that the agreement be in writing. Presumably, the same sort of agreement as provided for in Article II is meant, and it is difficult to see how the proponent could supply the enforcing State with a copy of it, as required by Article IV, unless it were in writing. ${ }^{79}$ For the same reason, it also appears that the choice of law by the parties must be in the agreement itself.

\section{Article V 1. (b): Lack of a Fair Opportunity to be Heard.}

The party against whom the award is invoked was not given proper notice of the appointment of the arbitrator or of the arbitration proceedings or was otherwise unable to present his case;

This clause incorporates a basic concept of due process into the Convention. The word "proper" was adopted to take care of the situation where the defendant was "under a legal incapacity." 80 The Conference adopted the phrase "or was otherwise unable to present his case" upon the insistence of the representative of the Netherlands that such a provision was needed to deal with the circumstance where force majeure or other cause operated to prevent a party from presenting his case, or where he was not given adequate opportunity to do so. $^{81}$

the economically weaker party. It could mean choice of a law that would let the stronger harass the weaker into an unwanted arbitration. It could mean as well choice of a law friendly to quick ex parte proceedings and careless as to requirements of service on the defending-party.

U.S. DeL. Rep. 18.

79. HATGHT 51-53.

80. U.N. Doc. No. E/CoNf. 26/SR.17, at 9, 14 (1958).

81. U.N. Doc. No. E/Conf. 26/SR.23, at 15 (1958). It should be noted that there is no specification of the standards for judging the propriety of the notice or the adequacy of the opportunity to be heard. By reference to the preceding clause, it can be argued that the law chosen by the parties or the law of the rendering State should govern. On the other hand, the concept of due process is closely linked with the public policy of the forum, and it can be expected that the enforcing State will apply its own standards of due process. 
Article V 1. (c): The Award or an Inseverable Part of it Exceeds the Submission to Arbitration.

The award deals with a difference not contemplated by or not falling within the terms of the submission to arbitration, or it contains decisions on matters beyond the scope of the stbmission to arbitration, provided that, if the decisions on matters submitted to arbitration can be separated from those not so submitted, that part of the award which contains decisions on matters submitted to arbitration may be recognized and enforced;

This basic provision merely reiterates the principle of Article $V 1$. (a) that an award should not be enforced against a party who never agreed to arbitrate the subject matter of it. The Conference passed it with no debate, save over the severability proviso. The Belgian and U.S.S.R. delegates argued for the deletion of the proviso on the ground that it would become a source of confusion. But the Indian delegate carried the day with the argument that:

If the enforcing court was not authorized to sever that (extraneous) matter from the remainder of the award and was obliged to refuse enforcement altogether merely because a small detail fell outside the scope of the arbitral agreement, the applicant might suffer unjustified hardship. ${ }^{82}$

\section{Article V 1.(d): Improper Composition of the Arbitral Tribunal or Improper Arbitral Procedure.}

The composition of the arbitral authority or the arbitral procedure was not in accordance with the agreement of the parties, or, failing such agreement, was not in accordance with the law of the country where the arbitration took place;

This clause provoked another debate over the subject of contractual autonomy. ${ }^{83}$ One group, led by the International Chamber of Commerce and France, advocated contractual freedom to designate an arbitral procedure independent of the law of any country. The other group, represented by Italy and the United States, argued for complete subjection of the arbitral procedure to the law of the country where the award was made. The resulting compromise lends itself to two interpretations. On the one hand, the absence of a provision restricting the parties to a choice of law indicates complete autonomy in the selection of the arbitral procedure. ${ }^{84}$ On the other hand, Article V 1. (a) re-

82. U.N. Doc. No. E/CoNF. 26/SR.17, at 9 (1958). The Conference again failed to specify what law would govern this issue of transgression of authority by the arbitrators, or the severability thereof. Application of the law of the forum would undercut the reliability of an arbitral agreement. The better approach would be to square the provision with Article V 1. (a) by looking to the law chosen by the parties or, absent such choice, to the law of the State where the award was made.

83. HaIGHT 56-59.

84. Cf. U.S. DEL. REP. 8-9:

The parties are free to choose the procedural law which is to govern their arbitration. It thus would not preclude the conduct of an arbitration under procedures at 
quires that the arbitral agreement be valid under "the law" to which the parties have subjected it. The Italian delegate was probably correct in stating that the paragraph "had been inserted on the understanding that the parties enjoyed discretion only to the extent that they could select the national law applicable in the matter." 80

\section{Article V 1. (e): The Award Is Not Binding or Has Been Set Aside or Sus- pended.}

The award has not yet become binding on the parties, or has been set aside or suspended by a competent authority of the country in which, or under the law of which, that award was made.

This paragraph reflects the inability of the Conference to agree on the solution to the problem of the "double exequatur." 86 No one wanted the Convention to require judicial proceedings in confirmation of the award in both the rendering and enforcing State. At the same time, an award which had been set aside by competent authority in the State where rendered should hardly be granted enforcement in another State.

The hardest question is the status in the enforcing State of an award that has not been set aside but is still subject to review in the rendering State by appeal or other procedures. The Conference rejected the requirement that the award be "final and operative" in the rendering State, yet was unwilling to make awards enforceable as soon as rendered.

In the confusion over the word "binding," there was no discussion of the phrase "or under the law of which." While this parallels the provision in Article V 1. (a) granting the parties the power to pick the law governing their agreement, the matter of setting aside the award is an entirely different matter. This phrase provides that when an award is rendered in one state under the law of a second state, the courts of that second state may set aside or suspend the award. Such a debatable result is probably not provided for under the national law of most of the States under whose law the award might have been made.

variance with or even illegal under the law of the place of arbitration and enforcement could be denied only if the procedures actually used constituted a breach of the agreement to arbitrate.

85. U.N. Doc. No. E/Conf. 26/SR.17, at 10 (1958). Even this limited freedom of choice has been questioned by the U.S. Delegation:

In the United States, however, the courts have tended to regard party choice of law as contrary to public policy at least with respect to some subject matter. While the public policy reservation in paragraph 2 would suffice to cover this situation, United States adherence to the convention would be misleading where paragraph 1 is concerned. Other countries would naturally assume that such adherence entailed acceptance of the principle of party choice of law to the extent contemplated by paragraph 1.

U.S. DeL. Rep. 20.

86. HaIGHT 34-35, 39-44, 59-65. 
Significantly, the paragraph fails to specify the grounds upon which the rendering State may set aside or suspend the award. While it would have provided greater reliability to the enforcement of awards under the Convention had the available grounds been defined in some way, such action would have constituted meddling with national procedure for handling domestic awards, a subject beyond the competence of the Conference.

\section{Article V 2. (a): Subject Matter Not Arbitrable}

The subject matter of the difference is not capable of settlement by arbitration under the law of that country;

This ground, and the following one, may be raised either by the defendant or by the competent authority before which the award is brought for enforcement.

This paragraph carries over the similar provision in Article 1. (b) of the Geneva Convention. ${ }^{87}$ France opposed its inclusion in the Convention on the ground that domestic standards of arbitrability should not be applied to international awards. ${ }^{88}$ Germany agreed, pointing out that matters which sharply conflicted with strong local policies could be handled under the public policy clause. ${ }^{89}$ The paragraph was adopted, however, and the enforcing State is thus empowered to decide the "arbitrability" of the dispute under its local standards. ${ }^{90} \mathrm{~A}$ certain degree of forum-shopping by successful parties is thus assured.

\section{Article V 2. (b): The Public Policy of the Forum}

The recognition or enforcement of the award would be contrary to the public policy of that country.

This paragraph has the effect of relegating the ultimate decision on the efficacy of the Convention to the good faith of the Contracting States. The only debate in the Conference centered on the proposal to add the phrase "or with fundamental principles of the law (ordre public)" after "public policy," which would have carried over the language of Article 1. (e) of the Geneva Conven-

87. Article 1 (b) of the Geneva Convention provides:

To obtain such recognition or enforcement, it shall, further be necessary : . .

(b) That the subject-matter of the award is capable of settlement by arbitration under the law of the country in which the award is sought to be relied upon;

The text of the Geneva Convention is reprinted in 3 Hudson, International LegisLATION 2153-60 (1931).

88. HAIGHT 66.

89. Ibid.

90. Compare the law of New York, for example, which forbids arbitration of almost all controversies "respecting a claim to an estate in real property, in fee or for life." N.Y. Crv. Prac. Act § 1448.

91. See generally HaIgHT 67-71. 
tion. ${ }^{92}$ This was in effect a debate over the scope of the phrase "public policy," and the decision not to add the second phrase may be read as a broadening of the definition of that term. ${ }^{93}$

\section{Enforcement of Foreign Arbitral Awards-Discretionary Stay on Adequate Security}

Article VI, which completes the basic operative section of the Convention, provides that when the losing party has applied for the setting aside or suspension of the award to the competent authority of the country in which, or under the law of which, the award was made, the enforcing forum may in its discretion adjourn the decision on the enforcement of the award. If the proponent of the award requests it, the forum may in its discretion order the other party to give suitable security.

This provision is a reasonable complement to Article V 1. (e), and eases the situations where the "double exequatur" problem arises. ${ }^{94}$ However, the provision is wholly discretionary, and the enforcing State is free to refuse adjournment and to enforce the award, nullification proceedings in the rendering State notwithstanding. The Convention contains no terms covering the situation where an award is later set aside by the rendering State. Presumably the defendant would be entitled to petition for relief and restitution under standard equitable doctrines of the enforcing State's national law.

\section{Effect on Other Treaties}

Article VII leaves undisturbed rights that have been or may be acquired under national law or under other treaties concerning the recognition and enforcement of arbitral awards. The Geneva Treaties, however, were felt to be too similar to the U.N. Convention to remain as conflicting obligations of the Contracting States. ${ }^{95}$ Article VII therefore provides that the two Geneva treaties shall cease to have effect between Contracting States "on their becoming bound and to the extent that they become bound by this Convention."

92. Article 1(e) of the Geneva Convention provides:

That the recognition or enforcement of the award is not contrary to the public policy or to the principles of the law of the country in which it is sought to be relied upon.

93. As noted above, France and Germany thought the phrase broad enough to cover arbitrability. Italy indicated that it would handle cases of res judicata under this heading. U.N. Doc. No. E/CoNr. 26/SR.17, at 15 (1958). Furthermore, the representatives of several countries thought that the problem of evasion of domestic law by two citizens arbitrating abroad could be taken care of under the heading of public policy. HaIGrit 70.

94. This Article has been criticized by the U.S. Delegation:

The provision for the posting of security by the defendant, however, appears open to grave objection. Although it is permissive in character, it has the unusual and exceptionable effect of penalizing a defendant for seeking to defend his rights . . .

U.S. DEz. Rep. 20.

95. HaIGHT 72-74. 
Thus, those members of the Geneva Convention who fail to accede to the U.N. Convention remain bound by their obligations thereunder. While the words of Article VII could be read as providing that Contracting States under the U.N. Convention who limit their accession by reservations remain bound by the Geneva Convention to the extent of such reservations, it seems unlikely that this was the intended meaning.

\section{States Eligible to Accede to the Convention}

Articles VIII and IX deal with the subject of the States which are eligible to become Contracting States under the Convention. The Polish delegate proposed that the Convention be open to all states, but this suggestion was rejected by the Conference. ${ }^{96}$ Thus the Convention may be ratified under Article VIII or acceded to under Article IX only by a Member of the United Nations or any other State which is or hereafter becomes a member of any specialized agency of the United Nations, or which is or hereafter becomes a party to the Statute of the International Court of Justice, or any state to which an invitation has been addressed by the General Assembly of the United Nations. ${ }^{97}$

\section{The Colonial Clause}

Article $\mathrm{X}$ authorizes a Contracting State to extend the Convention to all or any of the territories for the international relations of which it is responsible, either simultaneously with its ratification or accession to the Convention, or at any time thereafter by a notification addressed to the Secretary-General of the United Nations. With regard to those territories to which the Convention is not extended, a Contracting State need merely "consider the possibility" of taking the necessary steps to extend the Convention, subject, where necessary for constitutional reasons, to the consent of the Governments of such territories.

\section{The Federal Clause}

Article XI provides that, with respect to those articles of the Convention which come "within the legislative jurisdiction of the federal authority," the obligations of the federal Government of federal States shall be the same as those of unitary States. With respect to those Articles of the Convention that come "within the legislative jurisdiction of constituent states or provinces which are not, under the constitutional system of the federation, bound to take legislative action," the Federal Government need only favorably recommend such articles to its States. A federal contracting State must, upon request, furnish a statement of the extent to which any provisions of the Convention has been made effective in the federation by legislation or other action.

96. U.N. Doc. No. E/CoNF. 26/SR.19, at 3-4 (1958).

97. The U.S. Delegation unsuccessfully opposed this provision on the ground that it would permit signature of the Convention by unrecognized regimes. U.S. DEL. REP. 9. 
The Soviet bloc challenged this Article for permitting privileged federal states "to evade some of the obligations imposed by the Convention." A8 Australia, on the other hand, said that without the article its country "would, at best, be able to ratify the convention only after a long delay and, at worst, not at all." 00 On this basis of necessity, the article was adopted.100

The perplexing question of reciprocity in relation to this Article was discussed at length in the Conference. At this point, there was no general reciprocity clause like Article XIV in the Convention, but the need for such a provision in the federal clause was felt. Accordingly, the Conference adopted a paragraph 2 to Article XI, which read:

A federal or non-unitary State shall not be entitled to avail itself of this Convention against other States except to the extent that it is bound to apply this Convention. ${ }^{101}$

Norway then proposed to add the words:

And in particular not as to awards made in a constituent state or a province to which the State is not bound to apply the Convention. ${ }^{102}$

Norway's amendment was defeated by the strange vote of 6 to 1 , with 22 abstentions. Had this provision been inserted in the convention, it would have posed serious problems of interpretation both under the colonial clause and under the federal clause. ${ }^{103}$ Shortly thereafter the Conference adopted the reciprocity clause in Article XIV, and deleted this special reciprocity clause from Article XI. ${ }^{104}$

98. U.N. Doc. No. E/Conf. 26/SR.20, at 5 (1958).

99. Id. at 6 .

100. The federal clause has been criticized as useful only to federations with clearly defined legislative powers. E.g., U.S. DEL. REP. 21, 22:

The former [Art. XI] is so framed that practical application to the situation of the U.S. is impossible. This is mainly because the "federal state clause" as developed apparently had in mind a system in which there was a clear division of authority between central and local governments in arbitration matters. It evidently failed to visualize a system in which central and local governments maintained concurrent and even to some extent overlapping jurisdiction in arbitration matters...

This is not to say, however, that article XI is not well adapted to the requirements of some federal systems. It appears from the Conference debates, for example, that a provision in these terms is vital from the standpoint of Australia, where the central government appears to have no authority in arbitration matters and where thus there is no problem of concurrent jurisdiction.

101. U.N. Doc. No. E/Conf. 26/L.61, at 5-6 (1958).

102. HAIGHT 83.

103. Though proposed during the debate over the federal clause, this phrase would be a meaningless qualification on that clause. Either no U.S. awards could be enforced, since all such awards are rendered "in a constituent state," or every award could be enforced, since the U.S. would be "bound to apply the Convention" in the territory of every state.

104. HATGHT 83. 


\section{Reciprocity}

The Conference did not adopt a reciprocity clause until the last day, when Article XIV was inserted.

A Contracting State shall not be entitled to avail itself of the present Convention against other Contracting States except to the extent that it is itself bound to apply the Convention. ${ }^{105}$

The adopion of this Article gives States a defensive right to take advantage of another State's reservations with regard to territorial, federal or other provisions. The clause presumably will also cover the case where the courts of a State have placed a restrictive interpretation upon its obligations under the Convention. ${ }^{106}$

\section{Accession By The United States}

The United States was not a signatory to either the Geneva Protocol or the Geneva Convention, and the United States Delegation to the U.N. Conference has recommended that the United States not accede to the U.N. Convention. ${ }^{108}$

105. The Ad Hoc Committee has attempted to avoid such a clause as inappropriate for a convention on arbitration.

If a State made a reservation because of the special features of its domestic legislation-for example, because it regarded certain awards made abroad as domesticother States were obviously not compelled to adopt these special features. The $A d$ Hoc Committee had therefore been quite right in not basing the draft Convention on the idea of reciprocity, at least with regard to the possible reservations.

U.N. Doc. No. E/Conf. 26/SR.20, at 7 (1958).

106. The Conference also adopted some minor provisions. Under Article XIII, any Contracting State can denounce the convention by written notification to the SecretaryGeneral of the U.N., the denunciation to take effect one year after receipt of the notification. In like manner, a Contracting State which has extended the Convention to one of its territories under Article $\mathrm{X}$ may denounce the extension. If proceedings for the recognition or enforcement of an arbitral award have been instituted before the denunciation takes effect, they shall continue to be governed by the Convention.

Article XII deals with the time the convention becomes effective. Pursuant to this Article, the Convention came into force on June 7, 1959, between Israel, Morocco and the U.A.R. For any State becoming a Contracting Party in the future, the Convention shall become effective 90 days after deposit of the instrument of ratification or accession. Article XV requires the Secretary-General of the U.N. to keep the Contracting States posted on action taken by other States under various articles of the Convention. Article XVI deals with the authentic texts and certified copies of the Convention.

108. U.S. DEL. REP. 22:

In the light of the foregoing analysis of the convention, the Delegation recommends strongly that the United States not sign or adhere to the convention. In its view there are compelling legal and policy objections to such adherence, whether it be done without reservation, with reliance on the "federal state clause" or with a reservation specially adjusted to the requirements of the United States federal system.

The reasons for the Delegation's negative recommendation were summarized as follows: 
The issue of United States accession to the convention should be re-examined ${ }^{109}$ and decided on the basis of a realistic appraisal of the benefits to be gained by accession ${ }^{110}$ and the difficulty of the problems presented by the United States federal system.

\section{Benefits}

As to those countries which presently refuse to recognize or enforce United States awards, ${ }^{111}$ accession to the Convention by the United States would require such a country, if also a Contracting State, to recognize such awards as "binding" and to enforce them. In those countries where arbitral awards are recognized but given only a limited effect, ${ }^{112}$ the Convention would seem to require such States to grant United States and other foreign awards a more "binding" effect. In many States where United States awards are now enforceable, ${ }^{113}$ they are ineligible for the summary procedure of enforcement which that State gives to foreign awards covered by the Geneva Convention. ${ }^{114}$

1. The convention, if accepted on a basis that avoids conflict with State laws and judicial procedures, will confer no meaningful advantages on the United States.

2. The convention, if accepted on a basis that assures such advantage, will override the arbitration laws of a substantial number of States and entail changes in State and possibly Federal court procedures.

3. The United States lacks a sufficient domestic legal basis for acceptance of an advanced international convention on this subject matter.

4. The convention embodies principles of arbitration law which it would not be desirable for the United States to endorse.

Id. at 2 .

109. The House of Delegates of the American Bar Association adopted the following resolution on September 1, 1960:

Resolved that the American Bar Association recommend to the President and the Congress that the United Nations Convention on the Recognition and Enforcement of Foreign Arbitral Awards be ratified by the United States. . . .

See generally ABa International and Conparative Law Section, Report of the Committee on International Unification of Private Law (1960).

110. For a consideration of the benefits to be obtained by accession, see ABA INTERNational and Coarparative Law Section, Report of the Conmitree on International Unification of PrIVATE LAW (1959), and in particular the annexed letter of Arthur $\mathrm{H}$. Dean. Id. at C-3. Cf. Correspondence with American Businessmen, collected by the U.S. Council of the International Chamber of Commerce for Presentation to the State Department (Sept. 1959); Haight, American Foreign Trade and Investment Disputes, 14 ARB. J. (n.s.) 73, 81-82 (1959).

111. Cf. ABA International and Comparative Law Section, Report, op. cit. supra note 109 , at $11-12$.

112. See Buyitch, Treaty Law of Private Arbitration, 10 ARB. J. (n.s.) 188, 193 (1955).

113. E.g., West Germany enforces United States awards. See UN Economrc Conmission for Europe, Table of Bilateral Conventions Relating to the Enforcement of Arbitral Awards and the Organization of Commercial Arbitration Procedure 18 (1957).

114. For example, the British Arbitration Act, discussed above, equates awards covered by the Geneva Convention with domestic judgments. 
The anticipated extension of such procedure to awards covered by the U.N. Convention would expedite the enforcement of United States awards in that State. Even with regard to those countries where United States awards are presently enforced, membership in the Convention would standardize the enforcement procedure. United States businessmen going abroad to enforce awards would know what to expect in each of the Contracting States. Membership of the United States in a multilateral arbitral convention would also give United States businessmen much more flexibility in planning their foreign transactions. Instead of attempting to tie the settlement of disputes to the favorable law of one country, the drafters of international agreements could provide for much greater play in the selection of the place of settlement of disputes, confident of enforcement in all the Contracting States.

\section{Problems}

\section{Federalism-Enforcement in the State Courts}

The law of the vast majority of the states of the United States renders "future disputes" arbitration agreements revocable and unenforceable.115 In a proceeding to enforce an arbitral award based on such an agreement, the court will void the award if the defendant proves he revoked his promise to arbitrate before the award was rendered. Would the Convention require these state laws to be changed, so that foreign awards based on such agreements and covered by the Convention would have to be enforced by the state courts? The words themselves would not seem to require this. Article V speaks of enforcement of the award by "the competent authority" of a Contracting State. Presumably, a special administrative agency for the enforcement of awards under the Convention could satisfy this Article, and certainly the federal courts would. The Convention does not require that awards be enforceable in every court of general jurisdiction in the land.

Greater difficulties may be raised by Article II, which requires "the court" of a Contracting State to stay litigation instituted in contravention of the arbitral agreement. If "the court" were interpreted to mean only those courts designated as the "competent authority" (for example, the federal courts), enforcement of the Convention would be weakened to the extent that litigation in violation of its commands could be instituted in state courts. More effective enforcement might be obtained by construing the word "court" to mean every court, state or federal, where litigation involving an arbitrable dispute is instituted. Under this interpretation, no court would be able to proceed with litigation in defiance of an arbitration provision subject to the Convention. ${ }^{115 a}$

115. See 3 Anr. JUR. Arbitration \& Award \& 59 (1936).

115a. The scope of federal authority to govern the administration of state courts is unclear. The Federal Employers Liability Act does not expressly require state courts to give a remedy, but the Supreme Court has held that a state court may not close its doors to FELA cases if it affords a remedy for common law negligence actions. McKnett v. St. 
But this same result could also be reached without requiring state courts to take affirmative action if defendants desiring to stay the state proceedings were able to remove to a federal court empowered to stay the conflicting litigation.

\section{The Federal Arbitration Act as a Basis for Accession.}

The sole fount of federal power on which the Congress relied in enacting the Federal Arbitration Act was the Commerce Clause. Therefore this Act would satisfy the Convention's requirements only as to foreign awards involving commerce. Unless the United States limits its accession to commercial matters, a large number of foreign awards covered by the Convention would be unenforceable under the Act. Further, the Federal Arbitration Act does not apply to employment contracts, regardless of the amount of foreign commerce involved; the arbitration clauses in such contracts would be the basis for a large number of awards by the Convention but excluded by the Act. The Act is generally thought not to be a basis for original jurisdiction in the federal courts. ${ }^{110}$ Even the Lazrence case admitted this limitation. ${ }^{117}$ If original jurisdiction is held not available, the proponent of a foreign arbitral award could invoke the Federal Arbitration Act only if his award satisfied the $\$ 10,000$

Louis \& S.F. Ry., 292 U.S. 230, 234 (1934) ("A state may not discriminate against rights arising under federal law."). While the Court did hold that the state court was not obliged to give a FELA case the same type of jury that a federal tribunal would, Minneapolis \& St. L. R.R. v. Bombolis, 241 U.S. 211 (1916), that case has been qualified by holding that the state must give the plaintiff his "federal right" to have the issue of fraud tried by a jury, Dice v. Akron, C. \& Y.R.R., 342 U.S. 359 (1952), and to have his pleadings construed leniently. Brown v. Western Ry., 338 U.S. 294 (1949). But these cases do not support the proposition that state courts may be forced to give a remedy they presently refuse to give.

See Testa v. Katt, 330 U.S. 386 (1947) (state may not refuse to enforce a valid federal penal law). Compare McCarroll v. Los Angeles County Dist. Council of Carpenters, 49 Cal. 2d 45, 315 P.2d 322, cert. denied, 355 U.S. 932 (1957) (Congress may not compel a state court, in enforcing federal rights, to withhold a remedy usually available in the state court).

The Supreme Court has held that a state must afford a remedy for violation of the federal Constitution. Ward v. Comm'rs, 253 U.S. 17 (1920); Iowa-Des Moines Nat'l Bk. v. Bennett, 284 U.S. 239 (1931) ; General Oil Co. v. Crain, 209 U.S. 211 (1908). And the Court recently has upset the doctrine that arbitration is not substantive but merely a procedural remedy. Bernhardt v. Polygraphic Co., 350 U.S. 198 (1956). These cases and the Supremacy Clause would presumably be the basis for an argument that the state courts may be utilized for the enforcement of a federal arbitral policy with regard to foreign arbitral awards.

See generally, Note, 73 Harv. L. Rev. 1551 (1960); Hart \& WeCHsler, The Federal Courts aNd the Federal System 391-99, 470-77, 795 (1953).

116. The federal courts have no jurisdiction of motions to stay arbitration, absent some other basis of jurisdiction. Application of Rosenthal-Block China Corp., 183 F. Supp. 659 (S.D.N.Y. 1960); In re Arbitration between Local 91, ILGWU and Frankow Mfg. Co., 183 F. Supp. 671 (S.D.N.Y. 1960).

117. Robert Lawrence Co. v. Deveonshire Fabrics, Inc., 271 F.2d 402, 408 (2d Cir. 1959), ccrt. granted, 362 U.S. 909, zerit of cert. dismissed, 364 U.S. 801 (1960). 
jurisdictional amount and involved diversity of citizenship or some basis of federal subject matter jurisdiction. ${ }^{118}$ Because many claimants can probably satisfy these requirements, ${ }^{119}$ the number of foreign awards that would be excluded under these provisions may be relatively small, but every one would be in direct violation of the obligation of a Contracting State under the Convention. And if the Act does not create original jurisdiction, removal of state court litigation instituted in contravention of an arbitral agreement would not always be available.

It might be argued that, despite Judge Medina's dictum in Lazorence, the "federal right" recognized by that opinion can itself serve as a basis for federal question jurisdiction. ${ }^{120}$ Judge Medina's dictum that the Act cannot be the basis of section 1331 jurisdiction was based on the provision in section 4 that the party seeking to invoke the statutory procedure must petition a court which would otherwise have had jurisdiction. Since there is no similar restriction over the plenary action covered by section 2 of the Federal Arbitration Act, it would seem that a party's rights under section 2 would constitute federal question jurisdiction. And if the section 4 requirement were construed as a venue limitation rather than as a jurisdictional limitation, the Federal Arbitration Act could be interpreted to grant federal question jurisdiction even over the statutory proceeding.

But even if this new interpretation of the Act were accepted, other factors would still render the statute unsuitable as a basis for accession to the Convention. Since the Act provides only for a stay of federal court ${ }^{121}$ litigation, defendants in state court litigation would be unable to invoke the Act for a stay even if they could remove. Finally, the Act contains no provision for confirming foreign arbitral awards. Section 9 allows confirmation in the court specified by the parties in their agreement. If no such provision is contained in the agreement, then application may be made to the United States court in and for the district within which such award was made.122 A foreign award would not come literally within these words. While the section might have been read as not denying jurisdiction in any other federal court, the practice

118. See 28 U.S.C. $\$ \$ 1331-60$ (1958). See generally Moore, Comarentary on the United States Judictal Code IT 0.03(22)-0.03(27) (1949).

119. By virtue of 28 U.S.C. $\S 1332(a)(2)$, there is diversity of citizenship between citizens of a state and citizens or subjects of foreign countries.

120. This view is raised and discussed in Note, 69 Y YLE L.J. 847 (1960).

121. 9 U.S.C. $\$ 3$ (1958):

If any suit or proceeding be brought in any of the courts of the United States upon any issue referable to arbitration under an agreement in writing for such arbitration the court in which such suit is pending upon being satisfied that the issue involved in such suit or proceeding is referable to arbitration under such an agreement, shall on application of one of the parties stay the trial of the action until such arbitration has been had in accordance with the terms of the agreement, providing the applicant for the stay is not in default in proceeding with such arbitration. (Emphasis added.)

122. 9 U.S.C. $\S 9$ (1958). 
with respect to foreign awards has been to institute a common law contract action on the award, alleging the jurisdictional amount and diversity or some other basis for federal subject-matter jurisdiction. ${ }^{123}$ The continuation of such procedure under the Convention would violate both Article II and Article III.

\section{Going Beyond the Federal Arbitration Act}

\section{The Self-Executing Convention}

Creating an international obligation of the country is one thing; effectuating that obligation as municipal law is quite another. One method that has been tried is a declaration by the United States, in ratifying a treaty, that the treaty is self-executing and shall become, without further action, the domestic law of the United States. A typical example is that of treaties protecting the right of aliens to acquire or inherit property in the United States. ${ }^{124}$

The advantage of following this route with the U.N. Convention would be that the provisions of the Convention, in haec verba, would become the domestic law of the United States. The Convention would automatically grant federal question jurisdiction. ${ }^{125}$ Since the Convention does not seem to require all the courts in a nation to enforce the award, enactment as a self-executing treaty could be construed as requiring only federal courts to enforce the award. And, as suggested above, the stay provisions of the Convention could be met through the use of the removal power. The provisions would apply to all awards defined by the Convention, and the local procedure to be applied to such awards would be that spelled out in the Articles of the Convention.

\section{Supplementary Legislation}

A less controversial ${ }^{126}$ method for obtaining domestic enforcement of the Convention would be to enact supplementary legislation. Such legislation could be based not only on the Commerce Clause but also on the foreign affairs

123. E.g., Standard Magnesium Corp. v. Otto Fuchs, 251 F.2d 455 (10th Cir. 1957).

124. E.g., Treaty with France (1778), upheld in Chirac v. Chirac, 15 U.S. (2 Wheat) 259 (1817).

125. 28 U.S.C. $\S 1331$ (a) (1958) :

... Arises under the Constitution, laws or treaties of the United States.

See International Refugee Organization v. Republic S.S. Corp., 189 F.2d 858, 861 (4th Cir. 1951) (dictum).

126. An attempt to adopt a self executing treaty will probably raise both political and legal problems. There have been numerous attempts to amend the Constitution to limit the treaty power. One such attempt failed to pass the Senate by one vote. S.J. Res. 1, 83d Cong., 1st Sess.; 100 Cong. Rec. 2374-75 (1954). The "Bricker Amendment" to restrict the treaty power was again introduced on Feb. 24, 1961, as S.J. Res. 55, 87th Cong., 1st Sess. (1961).

The legal problems are also unsettled. For a recent decision holding invalid an attempt by Congress to enact domestic federal law by use of a treaty reservation, see Power Authority v. FPC, 247 F.2d 538 (D.C. Cir.), vacated as moot, 355 U.S. 64 (1957) ; 51 AM. 
power of Congress. ${ }^{127}$ It should explicitly establish the enforcement of arbitral agreements and awards covered by the Convention as a special basis of original federal jurisdiction in the District Courts. ${ }^{128}$ In view of the requirement that federal question jurisdiction be based on the creation of federal rights, ${ }^{128}$ presumably Congress would have to provide that the validity of arbitration agreements under the Convention be governed by federal substantive law..$^{130}$ This would require legislative enactment of the position taken by Judge Medina in Lawrence.

The coverage of this supplementary legislation should be as broad as the Convention itself. The exclusion of employment contracts involving foreign commerce should be eliminated. ${ }^{131}$ With regard to those arbitral agreements and awards to which the new legislation would apply, its provisions must match the Convention's requirements. The arbitral agreement must be "recognized." While the Convention does not expressly require specific performance of the agreement by court order, this has been available under the Federal Arbitration Act ${ }^{132}$ and there is no reason to cut back under the Convention. Judicial proceedings instigated in defiance of an arbitral agreement must be stayed at the instance of the defendant. A stay must be available not only for litigation instituted in the federal courts-as it is now under the Federal Arbitration Act-but also for state court litigation removed to the

J. IN'T L. 797 (1957). For conflicting views on the scope of the treaty power with respect to the enactment of domestic law, compare Looper, Limitations on the Treaty Powar in Federal States, 34 N.Y.U.L. Rev. 1045 (1959), with Henkin, Treaty Makers and the Law Makers; the Law of the Land and Foreign Relations, 107 U. PA. L. Rev. 903 (1959).

127. There appears no real need for the United States to limit its accession to commercial matters as provided in Article I(3). Awards on political matters and other subjects which the United States finds repugnant to its public policy can be adequately handled under that heading.

128. A special jurisdictional provision would be required to avoid the $\$ 10,000$ jurisdictional amount required by the basic federal question jurisdictional provision, 28 U.S.C. $\S 1337$ (1958). Even without such a special provision, it is arguable that the jurisdictional amount could be avoided by reliance upon 28 U.S.C. $\$ 1337$ (1958), which grants federal jurisdiction of civil actions arising under "any Act of Congress regulating commerce."

129. 28 U.S.C. $\S 1331$ (1958). See Association of Westinghouse Salaried Employees v. Westinghouse Elec. Corp., 348 U.S. 437 (1955).

130. This is the course suggested by the Supreme Court's decision in Textile Workers v. Lincoln Mills, 353 U.S. 448 (1957), involving a similar attempt to confer federal jurisdiction under $\S 301$ of Taft-Hartley, 61 Stat. 156 (1947), 29 U.S.C. § 185(a) (1958).

For the view that a "protective jurisdiction" to apply state law does not exceed Article III, see Teamsters Union v. Mead, 230 F.2d 576 (1st Cir. 1956); Textile Workers v. Lincoln Mills, supra, at 459-60 (concurring opinion); HART \& WECHSLER, THE FEDERAL Courts and The Federal System 744-47 (1953). But cf. Textile Workers v. American Thread Co., 113 F. Supp. 137 (D Mass. 1953) ; Textile Workers v. Lincoln Mills, supra, at 469-84 (dissenting opinion).

131. Quaere whether the "commercial" reservation may be used to exclude labor matters. Such matters are within the "Commerce Clause" of the United States Constitution, but are not within the "commercial" codes of some civil law countries.

132. 9 U.S.C. $\$ 4$ (1958). 
federal courts. ${ }^{133}$ The foreign arbitral award must be recognized and enforced according to the conditions laid down in the Convention. Confirmation of the award in the federal courts must be made available.

The procedure for enforcement need not be identical with that applicable to interstate awards under the Federal Arbitration Act-a certain amount of time spent in ascertaining whether the Convention applies will be an unavoidable discrimination. But once the court has assured itself that the Convention does apply, there should be no reason for treating the award any differently from interstate awards. All the normal controls on the arbitral process are contained in Article V.

Ideally, perhaps, there should be a full-scale revision of the Federal Arbitration Act to make it conform to the internationally accepted procedures set forth in the Convention. There is no immediate reason for having arbitral provisions for interstate awards with less scope or less modern procedures than those for foreign awards. But this is not essential to the carrying out of United States obligations under the Convention. All that is required is a specific amendment to the Federal Arbitration Act, extending to all arbitral agreements and awards covered by the Convention the benefit of the Act's provisions with regard to stays of litigation, enforcement of the arbitral agreement, and confirmation of the award. The latter two remedies would have to be available in any federal court with personal jurisdiction of the parties.

\section{Limiting Accession to the Federal Courts-The Problem of Reciprocity.}

The United Sates should explicity limit accession to the federal courts, in the sense that those courts will be the only tribunals in which the obligations of the United States under the Convention may be enforced. It is neither necessary nor desirable to make a formal reservation to this effect, in view of the Resolution of the Conference forbidding any additional reservations. The best technique would be to issue a declaration simultaneously with accession, defining the competent authority for enforcement of foreign arbitral awards to be the federal courts of the United States. Article II's requirements for a stay of conflicting litigation could be handled internally, by making actions involving matters arbitrable under the Convention a basis for original jurisdiction in the federal courts.

Limited accession, however, presents a problem of reciprocity, under Article XIV. In the courts of a majority of the states of the United States, foreign arbitral agreements will not be recognized, stays of conflicting litigation will not be granted, and a foreign arbitral award will still be unenforceable if the agreement was revoked prior to the handing down of the award. Of course, the

133. Cf. 28 U.S.C. $\S 2283$ (1958). "A court of the United States may not grant an injunction to stay proceedings in a State court except as expressly authorized by Act of Congress, or where necessary in aid of its jurisdiction, or to protect or effectuate its judgments." For a review of cases involving federal court injunctions of state court proceedings, see HART \& WECHSLER, op. cit. supra note 130, at 1057-78. 
existence of such state doctrines would not detract from the actual enforcement of the Convention by the United States, because any award or agreement subject to the Convention could be enforced in a federal court applying federal law. Nevertheless, it is possible that contracting states might invoke Article XIV to deny the benefits of the Convention to arbitral agreements governed by the law of those states and awards rendered in the territory or under the laws of such states. ${ }^{134}$ But even this possibility is unlikely. The suggested federal legislation would satisfy the requirements of the Convention in the only relevant aspect by guaranteeing enforcement of those awards which are covered by the Convention.

On the practical level, it is exceedingly doubtful that countries which have espoused the cause of international arbitration to the extent of acceding to the Convention would demand a fundamental alteration in the United States federal system as a condition of reciprocal enforcement. On the other hand, it is to be expected that the courts of such countries will require some proof that the United States awards presented for enforcement do come within the coverage of the Convention. If the United States does not limit its accession to commercial matters, then it would be an easy matter for the other country to determine if the award is "foreign." But if the United States, pursuant to Article I(3), limits its accession to matters "considered as commercial" under United States law, the determination of reciprocity may become particularly difficult for the courts of the enforcing Contracting State, unless some guide to the meaning of "commercial" under United States law is adopted concurrently. The enforcing Contracting State is free to prescribe the procedure for determining if the award tendered is entitled to the benefits of the Convention, subject always to the prohibition in Article III of substantially more onerous conditions than are imposed upon the enforcement of domestic awards.

134. The U.S. Delegation held this view (although it is not clear whether this view would have been advanced if the Delegation were contemplating the enforcement scheme suggested above). U.S. DEL. REP., at 22:

Conversely, other countries would be entitled to deny enforcement to United States awards if rendered under the laws of any of the States. This automatically limits the benefits of the convention to the relatively small number of awards rendered under the Federal Arbitration Act. 


\section{THE YALE LAW JOURNAL}

\begin{tabular}{lll}
\hline VOLUMe 70 & JUNE 1961 & NUMBer 7 \\
\hline
\end{tabular}

\begin{tabular}{|c|c|}
\hline \multicolumn{2}{|c|}{$\begin{array}{l}\text { ROBERT E. HUDEC } \\
\text { Editor-in-Chief }\end{array}$} \\
\hline $\begin{array}{l}\text { NeAle M. Albert } \\
\text { LAWREnCE G. GoOdMan } \\
\text { DAVID M. TrubeK } \\
\text { JeRE A. Young }\end{array}$ & $\begin{array}{l}\text { HARRISON J. GoldIN } \\
\text { Article \& Book } \\
\text { Revieze Editor }\end{array}$ \\
\hline $\begin{array}{c}\text { JERE A. Young } \\
\text { Note \& Conment } \\
\text { Editors }\end{array}$ & $\begin{array}{c}\text { SIDNEY M. WoLINSKY } \\
\text { Topics \& Case } \\
\text { Editor }\end{array}$ \\
\hline & \\
\hline
\end{tabular}

Burton J. AHRENS

Hershel Y. Allerhand

Dougras R. Ayer

Charles S. Battles, Jr.

Henry G. Bisgater

JOSEPH S. BORUS

Thomas B. BrackeN

Carroll W. Brewster

Stephen A. Brown

Alan M. Dershowttz

JaN Deutsch

George B. DRIESEN

Benjanim S. DuVal, Jr.
JoEL J. FINER

JaAIES O. FrEEDAMAN

JAMES H. GILLESPIE

David I. GoldblatT

William S. Greenawalt

David C. Greer

JoHN P. HeINZ

Algernon S. Holderness, JR.

Arthur P. Jacobs

PhILIP F. JoHNSON

Robert A. Johnson

LAWRENCE P. KLAMON

ZANE KLEIN

GeORGe LeFCOE
ALAN H. Levine

Charles E. Lewis

John T. Marshali

JAMES L. MrtCheLL

Thomas S. Nichols

Peter G. Platy

Stoddard D. Platt

Charles F. Ruchards, JR.

David A. Rosen

SIDNEY G. SALTZ

Carol W. TRENCHER

ADAMI WALINSKY

HARRY J. WEXLER

MARIE McMaHoN

Business Secretary

\section{CONTRIBUTORS TO THIS ISSUE}

Grant Girmore. A.B. 1931, Yale College; Ph.D. 1936, LL.B. 1942, Yale University. Member, New York Bar. William K. Townsend Professor of Law, Yale University.

Leonard V. Quigley. A.B. 1953, Holy Cross College; LL.B. 1959, Harvard University. Member, New York Bar.

Marilyn Conen. A.B. 1958, Connecticut College for Women; Third Year Student, Yale Law School.

Theodore W. Phirurps. A.B. 1957, University of California, Berkeley; Third Year Student, Yale Law School. 